\title{
TMEM138 Gene
}

National Cancer Institute

\section{Source}

National Cancer Institute. TMEM138 Gene. NCI Thesaurus. Code C101658.

This gene plays a role in cilium formation. 